AperTO - Archivio Istituzionale Open Access dell'Università di Torino

\title{
Evaluation of Nitrogen Effect on Ultrasound-Assisted Oxidative Desulfurization Process
}

\section{This is the author's manuscript}

Original Citation:

Availability:

This version is available http://hdl.handle.net/2318/157378

since

Published version:

DOI:10.1016/j.fuproc.2014.05.031

Terms of use:

Open Access

Anyone can freely access the full text of works made available as "Open Access". Works made available under a Creative Commons license can be used according to the terms and conditions of said license. Use of all other works requires consent of the right holder (author or publisher) if not exempted from copyright protection by the applicable law. 


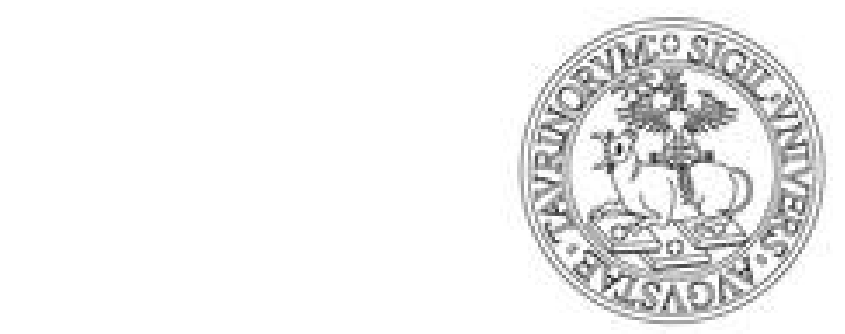

\section{UNIVERSITÀ DEGLI STUDI DI TORINO}

This Accepted Author Manuscript (AAM) is copyrighted and published by Elsevier. It is posted here by agreement between Elsevier and the University of Turin. Changes resulting from the publishing process - such as editing, corrections, structural formatting, and other quality control mechanisms - may not be reflected in this version of the text. The definitive version of the text was subsequently published in FUEL PROCESSING TECHNOLOGY, 126, 2014, 10.1016/j.fuproc.2014.05.031.

You may download, copy and otherwise use the AAM for non-commercial purposes provided that your license is limited by the following restrictions:

(1) You may use this AAM for non-commercial purposes only under the terms of the CC-BY-NC-ND license.

(2) The integrity of the work and identification of the author, copyright owner, and publisher must be preserved in any copy.

(3) You must attribute this AAM in the following format: Creative Commons BY-NC-ND license (http://creativecommons.org/licenses/by-nc-nd/4.0/deed.en), 10.1016/j.fuproc.2014.05.031

The definitive version is available at: http://linkinghub.elsevier.com/retrieve/pii/S0378382014002367 


\title{
Evaluation of nitrogen effect on ultrasound-assisted oxidative desulfurization process
}

\author{
Matheus A.G. Nunes a, Paola A. Mello a, Cezar A. Bizzi a, Lisarb O. Diehl a, Elizabeth M. Moreira ${ }^{\text {b, }}$ \\ Wladmir F. Souza ${ }^{b}$, Emanuela C. Gaudino ${ }^{c}$, Giancarlo Cravotto ${ }^{c}$, Erico M.M. Flores a,* \\ a Departamento de Química, Universidade Federal de Santa Maria, 97105-900 Santa Maria, RS, Brazil \\ b Centro de Pesquisas e Desenvolvimento Leopoldo Américo Miguez de Mello, CENPES/PETROBRAS, 21941-915 Rio de Janeiro, RJ, Brazil \\ ${ }^{c}$ Dipartimento di Scienza e Tecnologia del Farmaco, Università di Torino, Via P. Giuria 9, 10125 Torino, Italy
}

\author{
Article \\ Article history: \\ Received 27 February 2014 \\ Received in revised form 20 May 2014 \\ Accepted 31 May 2014 \\ Available online 24 June 2014 \\ Keywords: \\ Ultrasound-assisted oxidative denitrogenation \\ Desulfurization \\ Diesel oil \\ Petroleum product feedstock \\ ODS
}

\begin{abstract}
A novel procedure based on ultrasound-assisted oxidative desulfurization was applied for diesel oil treatment, which was performed simultaneously to ultrasound-assisted oxidative denitrogenation (UAODN) in order to minimize $\mathrm{N}$ interference over $\mathrm{S}$ oxidation. The effect of ultrasonic irradiation time, reagent amount and the nature of extraction solvent were evaluated. A petroleum product feedstock containing quinoline was used as a model nitrogen compound and acetic acid and hydrogen peroxide were used as oxidizing agents. Nitrogen removal above $95 \%$ was obtained for the model oil after $5 \mathrm{~min}$ of ultrasonic irradiation $(20 \mathrm{kHz}, 750 \mathrm{~W}, 40 \%)$. Additionally, this study showed that quinoline can reduce the oxidative desulfurization efficiency of an oil containing dibenzothiophene. The application of oxidative treatment without ultrasound showed that nitrogen and sulfur removal efficiencies for five diesel oil samples were considerably lower (lower than 22 and $40 \%$ for nitrogen and sulfur, respectively). The UAODN procedure was applied for the treatment of a hydrotreated petroleum product feedstock and samples of diesel oil with nitrogen and sulfur content up to 226 and $375 \mathrm{mg}$ $\mathrm{kg}^{-1}$, respectively. Under optimized conditions, nitrogen content below $20 \mathrm{mg} \mathrm{kg}^{-1}$ was obtained and the feasibility of ultrasound for simultaneous denitrogenation and desulfurization was demonstrated.
\end{abstract}

(C) 2014 Elsevier B.V. All rights reserved.

\section{Introduction}

The production of diesel oil and other fuels with low levels of polluting compounds is required to meet fuel specifications and thus the removal of some contaminants such as sulfur, nitrogen, oxygen and metals is necessary $[1,2]$. Hydrodesulfurization (HDS) is currently the industrial refining process used for sulfur removal from petroleum fractions, and it generally occurs simultaneously with hydrodenitrogenation (HDN). In most cases, sulfur and nitrogen compounds are refractory to conventional HDS and HDN processes, and moreover the respective catalysts can be poisoned by nitrogen compounds. In order to overcome these drawbacks, usually the hydrotreatment process has been operated under severe conditions of pressure and temperature (generally from 20 to $100 \mathrm{bar}$ and from 300 to $400{ }^{\circ} \mathrm{C}$, respectively) [2]. Furthermore, pollution caused

by $\mathrm{NO}_{\mathrm{x}}$ and $\mathrm{SO}_{\mathrm{x}}$ emissions has been a critical point to the environment $[1,3,4]$.

Although hydroprocessing has been considered a very important step in petroleum refining industry, it requires expensive processes in cases of deep sulfur and nitrogen removals. In order to satisfy the legislation for commercial fuels, new emerging technologies have been

Corresponding author. Tel.: +555532209445

E-mail address: ericommf@gmail.com (E.M.M. Flores). developed and many works on sulfur removal procedures, such as biodesulfurization [5,6], extraction with ionic-liquids [7,8], and oxidative desulfurization (ODS) [9-12] have been reported.

The presence of nitrogen compounds is known to impair desulfurization activity, mainly due to competitive reactions of nitrogen com- pounds with hydrogen as well as nitrogen adsorption onto catalyst surface [13,14]. The inhibiting effect of nitrogen compounds such as quinoline, indole and carbazole on the hydrodesulfurization process has been observed even at nitrogen concentrations below $15 \mathrm{mg} \mathrm{kg}^{-}$[15]. Due to this limitation, some nonconventional processes for nitro-

gen removal have been proposed, resulting in better efficiency. Some of these processes are based on the use of microbiological denitrogenation [16-18], ionic-liquids [19], selective adsorption [20,21] and oxidative denitrogenation (ODN) [22,23].

The oxidative process for desulfurization and denitrogenation is a promising methodology for high efficiency sulfur and nitrogen removal as it can be conducted at relatively low temperature and atmospheric pressure, and does not require hydrogen consumption. In this process, sulfur and nitrogen compounds can be oxidized by some reagents as hy- drogen peroxide/formic acid [3], hydrogen peroxide/acetic acid [24] or hydroperoxide $/ \mathrm{MoO}_{3}-\mathrm{Al}_{2} \mathrm{O}_{3}$ [23]. Due to the higher polarity, oxidized sulfur or nitrogen compounds can be removed by a liquid-liquid extrac- tion or adsorption step [22,25-27]. 
The use of ultrasound (US) in chemistry can intensify chemical reac- tions due to several effects, especially those related to cavitation phe-

nomenon [28-30]. Cavitation occurs when mechanical vibrations are generated and transmitted to a liquid medium, producing a series of compression and rarefaction cycles that may exceed the attractive forces of the molecules in the medium, producing cavitation bubbles. In some conditions, the collapse of bubbles in liquids provides a micro- environment with temperature and pressure up to $20,000 \mathrm{~K}$ and $1000 \mathrm{~atm}$, respectively [31].

The feasibility of combining oxidizing conditions and US energy for sulfur removal has been proposed in some works [32-36]. However, in a similar way to conventional hydrodesulfurization process, the presence of nitrogen compounds decreases the efficiency of sulfur removal, and most of works do not evaluate the efficiency of ultrasoundassisted ODN, or even the effect of nitrogen in ODS processes.

In the present work, an ultrasound-assisted oxidative denitrogenation (UAODN) procedure using an oxidizing system based on hydrogen per- oxide and acetic acid is proposed for the oxidation of nitrogen and its re- moval from a petroleum product feedstock. The inhibiting effect of quinoline on the oxidative desulfurization of dibenzothiophene was also evaluated. Selected ultrasoundassisted oxidative desulfurization (UAODS) conditions were performed simultaneously to UAODN for the treatment of diesel oils with nitrogen concentration ranging from 86 to $226 \mathrm{mg} \mathrm{kg}^{-1}$ and sulfurconcentrationranging from 136 to $375 \mathrm{mg} \mathrm{kg}^{-1}$. The effect of S:N molar ratio on UAODS was evaluated from 1:0.1 to 1:2, respectively.

\section{Experimental}

\subsection{Apparatus}

Ultrasonic treatment was performed using a $20 \mathrm{kHz}$ and $750 \mathrm{~W}$ nominal power ultrasonic processor (Sonics and Materials Inc., Model VC 750, Newtown, USA) with a titanium ultrasonic probe (13 mm diam- eter, $254 \mathrm{~mm}$ long), which was dipped directly into the reaction mix- ture. Experiments were performed in a $250 \mathrm{~mL}$ three-neck conic glass reactor (Sonics and Materials, Inc.) with a glass jacket for temperature control using a circulating water bath (Model MCT 110 Plus, Servylab Ltda., São Leopoldo, Brazil). After US treatment, a glass separator funnel was used for the solvent extraction step. Comparative experiments without US were performed with a high speed mechanical stirrer (Model PT 3100 D, Polytron, Switzerland) using a stainless steel dispers- ing aggregate (20 $\mathrm{mm}$ of diameter) at $2000 \mathrm{rpm}$.

Analysis of reaction products after quinoline oxidation with acetic acid and $\mathrm{H}_{2} \mathrm{O}_{2}$ in toluene was performed using gas chromatography coupled to mass spectrometry (GC-MS, Agilent 6850/5973 Network). Chromatographic and detection conditions are shown in Table 1.

Total nitrogen and sulfur concentration in petroleum product feed- stock and diesel oil samples were determined using a total nitrogen and sulfur analyzer with chemiluminescence and fluorescence detectors (direct injection method, Antek Instruments, Model 9000 series

Table 1

Conditions used in GC-MS for quinoline and oxidative products analysis.

\begin{tabular}{ll}
\hline Parameters & Conditions \\
\hline Injector & $250^{\circ} \mathrm{C}$ \\
Temperature & $1.2 \mathrm{~mL}$ min \\
Carrier gas flow rate $(\mathrm{He})$ & $1 \mu \mathrm{L}$ \\
Injection volume & $20: 1$ \\
Split/Splitless & $50^{\circ} \mathrm{C}(3 \mathrm{~min})$ \\
Oven & $80^{\circ} \mathrm{C}\left({ }^{\circ} \mathrm{C} \mathrm{min}^{\lrcorner}\right)$ \\
Initial temperature & $300^{\circ} \mathrm{C}\left(10^{\circ} \mathrm{C} \mathrm{min}\right.$, ,hol 10min) \\
& $\mathrm{MS}$ \\
Final temperature & $280^{\circ} \mathrm{C}$ \\
Detector & $\mathrm{HP}-5 \mathrm{MS}(30 \mathrm{~m} \times 0.25 \mathrm{~mm} \times 0.25 \mu \mathrm{mm})$ \\
Temperature & \\
Column &
\end{tabular}

nitrogen/sulfur analyzer, Texas, USA), according to ASTM D 4629-96 and D 5453-06 for nitrogen and sulfur determination, respectively [37,38].

A viscometer (Stabinger, Model SVM 3000, Anton Paar GmbH, Graz, Austria) was used for the determination of kinematic viscosity $\left(\mathrm{mm}^{2} \mathrm{~s}^{-1}\right)$ anddensity $\left(\mathrm{g} \mathrm{cm}^{-3}\right)$ of samples before and after thetreat-ment according to ASTM D 7042-04 method [39].

\subsection{Reagents and materials}

In the proposed UAODN procedure, $50 \%$ hydrogen peroxide $\left(\mathrm{H}_{2} \mathrm{O}_{2}\right.$, Synth, Diadema, Brazil) and glacial acetic acid $\left(\mathrm{AcOH}, \mathrm{C}_{2} \mathrm{H}_{4} \mathrm{O}_{2}\right.$, $1.05 \mathrm{~kg} \mathrm{~L}^{-1}$, Vetec, Riode Janeiro, Brazil) were used. Quinoline

$\left(\mathrm{C}_{9} \mathrm{H}_{7} \mathrm{~N}, 98 \%\right.$, Aldrich, St. Louis, USA) was used as a model nitrogen compound for the optimization of process parameters. A synthetic oil solution was then prepared by dissolving quinoline in a hydrotreated petroleum product feedstock, resulting in a solution with total nitrogen concentration of 252 $\mathrm{mg} \mathrm{kg}^{-1}$. In order toevaluate the effect of nitrogen content on desulfurization process, dibenzothiophene (DBT,

$\mathrm{C}_{12} \mathrm{H}_{8} \mathrm{~S}, \geq 98 \%$, Merck, Darmstadt, Germany) was used as model sulfur

compound. Quinoline was added to a hydrotreated petroleum product feedstock (similar composition to diesel oil) containing $211 \mathrm{mg} \mathrm{kg}\urcorner$ lof sulfur (as dibenzothiophene), resulting in $\mathrm{S}: \mathrm{N}$ molar ratios of 1:0.1, 1:0.3, 1:0.5, 1:1 and $1: 2$. The properties of the hydrotreated petroleum product feedstock employed in this study are shown in Table 2 .

Toluene $\left(\mathrm{C}_{7} \mathrm{H}_{8}, 0.87 \mathrm{~kg} \mathrm{~L}^{-1}\right)$, ethanol ( $\left.\mathrm{EtOH}, \mathrm{C}_{2} \mathrm{H}_{5} \mathrm{OH}, 0.79 \mathrm{kgL}^{-1}\right)$ and methanol $\left(\mathrm{MeOH}, \mathrm{CH}_{3} \mathrm{OH}, 0.79 \mathrm{~kg} \mathrm{~L}^{-1}\right)$ were purchased from Vetec.

Reference solutions for sulfur and nitrogen determination in the oil phase were prepared by dissolving a white mineral oil (AccuStandard, Inc., 5000 $\mathrm{mg} \mathrm{kg}^{-1}$ sulfurcontent, New Haven, USA) and pyidine

$\left(\mathrm{C}_{5} \mathrm{H}_{4} \mathrm{~N}, \geq 995 \%\right.$, Merck) in toluene. The ultrasonic probe and all the

glass materials were cleaned with toluene, ethanol and deionized water.

\subsection{Experimental procedures}

For the initial experiments, UAODN conditions were similar to those previously optimized for diesel oil desulfurization [40]. In this way, $25 \mathrm{~mL}$ of quinoline enriched petroleum product feedstock were heated at $90{ }^{\circ} \mathrm{C}$ and sonicated for 9 min running at $40 \%$ amplitude with $2.5 \mathrm{~mL}$

glacial acetic acid and amounts of $50 \% \mathrm{H}_{2} \mathrm{O}_{2}$ ranging from 0 to $1.0 \mathrm{~mL}$. After selecting the $\mathrm{H}_{2} \mathrm{O}_{2}$ amount, the effect of glacial acetic acid volume ( 0 to $2.5 \mathrm{~mL}$ ) was investigated for petroleum feedstock and for diesel oil samples $(25 \mathrm{~mL})$. Using the selected reagent amounts, reaction times of 1 to 9 min were investigated and US amplitude of 30 to $70 \%$ was evalu- ated. It is important to point out that all the experiments were carried out at atmospheric pressure $(\mathrm{n}=3)$.

After US treatment, the separation of oil and aqueous phases was spontaneous (less than $1 \mathrm{~min}$ ), and the oil phase was further extracted by manual shaking using a polar solvent $\left(\mathrm{EtOH}, \mathrm{MeOH}\right.$ or $\left.\mathrm{H}_{2} \mathrm{O}\right)$ and a glass separator funnel. Nitrogen and sulfur were determined in oil phase after the extraction step in order to evaluate the efficiency of the proposed procedure. Fig. 1 shows the overall procedure and the sequence of optimization performed.

In order to evaluate the quinoline oxidation after UAODN process, $25 \mathrm{~mL}$ of quinoline solution in toluene ( $150 \mathrm{mg} \mathrm{kg}^{-1}$ as $\mathrm{N}$ ), $5 \mathrm{~mL}$ of $50 \%$

Table 2

Properties of hydrotreated petroleum product feedstock.

\begin{tabular}{lll}
\hline Property & Feedstock (oil) \\
\hline Hydrogen content $(\%, \mathrm{w} / \mathrm{w})$ & 13.6 \\
Carbon content $(\%, \mathrm{w} / \mathrm{w})$ & 86.4 & \\
Sulfur (original, $\left.\mathrm{m} \mathrm{kg}^{-}\right)$ & 3.6 & \\
Nitrogen (original, $\left.\mathrm{mg} \mathrm{kg}^{-}\right)$Density & $\mathrm{b} 0.5$ & \\
$20^{\circ} \mathrm{C} / 4^{\circ} \mathrm{C}_{\left(\mathrm{g} \mathrm{cm}^{-3}\right)}$ & 0.8362 & 266 \\
Distillation temperature (initial b.p., $\left.{ }^{\circ} \mathrm{C}\right)$ & $10 \%(\mathrm{v} / \mathrm{v})$ & 328 \\
& $50 \%(\mathrm{v} / \mathrm{v})$ & 361 \\
\hline
\end{tabular}




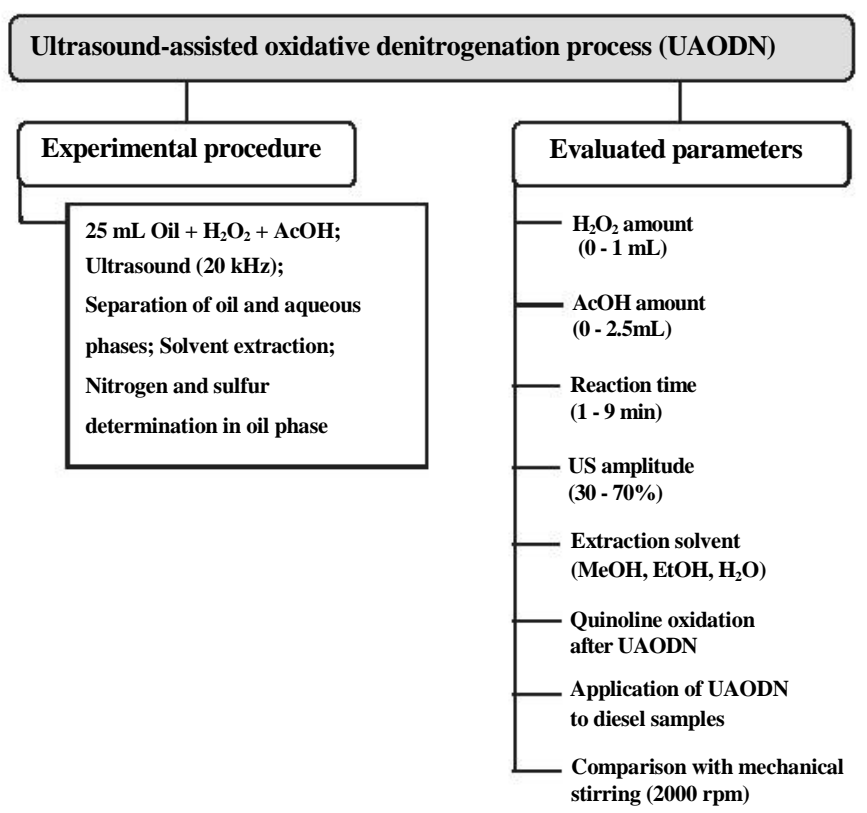

Fig. 1. Experimental conditions and evaluated parameters for UAODN process.

$\mathrm{H}_{2} \mathrm{O}_{2}$ and $15 \mathrm{~mL}$ of glacial acetic acid were treated at $80{ }^{\circ} \mathrm{C}$ for 9 min with magnetic stirring at $350 \mathrm{rpm}$. Final reaction medium presented two different phases in the reaction vessel. Toluene phase was washed with $15 \mathrm{~mL}$ of water and dried with anhydrous $\mathrm{Na}_{2} \mathrm{SO}_{4}$. After filtration, the organic phase was analyzed by GC-MS.

After optimization of UAODN conditions, the procedure was applied to the ultrasonic treatment of five diesel oil samples, named D1, D2, D3, D4 and D5, as shown in Table 3. In addition, experiments using optimized US conditions but with mechanical stirring (2000 rpm) were carried, and the effect of US over ODS and ODN efficiency was evaluated.

All statistical calculations were performed using GraphPad InStat software (GraphPad InStat Software Inc., Version 3.0, 1997). A 95\% confidence level was adopted for all comparisons. Comparisons between two averages were performed using a Student-test, whereas the Tukey-Kramer test was used for comparison of three or more averages.

\subsection{Energy consumption}

The energy input to the reaction was determined by calorimetry, ac- cording to Kimura et al. [41]. This evaluation was performed with $25 \mathrm{~mL}$ of diesel oil 1, applying ultrasound at $20 \mathrm{kHz}$, set at $40 \%$ of amplitude, for $5 \mathrm{~min}$. The temperature was monitored using a digital thermometer and the power $(\mathrm{P})$ was determined according to the equation $\mathrm{P}=\mathrm{m} \mathrm{C}_{\mathrm{p}} \mathrm{dT}$, where $\mathrm{dT}$ is the variation of temperature, $\mathrm{C}_{\mathrm{p}}$ is the specific heat of diesel oil $1\left(2130 \mathrm{~J} \mathrm{~kg}^{-1} \mathrm{~K}^{-1}\right)$, and mis the diesel oil mass $(\mathrm{kg})$. The deter-

mined power (Joules) can be related to the sonication time (s), to give the power (watts) transferred to the solution. In addition, the power in- tensity $\left(\mathrm{W} \mathrm{dm}^{-3}\right)$ [42] was also determined for the used ultrasonic sys-tem. According to the procedure described, the energy input for the treatment of $25 \mathrm{~mL}$ of diesel oil was about $10 \mathrm{~W}$ and the power intensity was $400 \mathrm{~W} \mathrm{dm}^{-3}$.

Table 3

Properties of diesel oil samples used in UAODN treatment.

\begin{tabular}{|c|c|c|c|c|c|}
\hline Samples ${ }^{\mathrm{a}}$ & Nitrogen concentration $\left(\mathrm{mg} \mathrm{kg}^{\lrcorner}\right)$ & Sulfur concentration ( $\mathrm{mg} \mathrm{kg}^{-}$) & $\mathrm{S}: \mathrm{N}$ molar ratio & Density $\left(\mathrm{g} \mathrm{cm}^{-3}, 20^{\circ} \mathrm{C}\right)$ & Viscosity $\left(\mathrm{mm}^{2} \mathrm{~s}^{-1}, 40^{\circ} \mathrm{C}\right)$ \\
\hline D1 & $143 \pm 3$ & $136 \pm 5$ & $1: 2.40$ & 0.8681 & 3.9156 \\
\hline $\mathrm{D} 2$ & $226 \pm 4$ & $249 \pm 4$ & $1: 2.07$ & 0.8672 & 4.1792 \\
\hline D3 & $158 \pm 4$ & $226 \pm 5$ & $1: 1.60$ & 0.8682 & 4.3167 \\
\hline D4 & $119 \pm 5$ & $319 \pm 3$ & $1: 0.85$ & 0.8510 & 2.7072 \\
\hline D5 & $86 \pm 1$ & $375 \pm 9$ & $1: 0.52$ & 0.8484 & 2.3580 \\
\hline
\end{tabular}

\section{Results and discussion}

\subsection{Quinoline oxidation after UAODN process}

A solution of quinoline in toluene $\left(150 \mathrm{mg} \mathrm{kg}^{-1}\right.$ of $\left.\mathrm{N}\right)$ was treated byreaction with acetic acid and $\mathrm{H}_{2} \mathrm{O}_{2}$ using US. After the oxidative step, the organic phase was treated for further analysis by GC-MS. An aliquot was analyzed in order to confirm the formation of ion $\mathrm{m} / \mathrm{z} 145$, corresponding to the oxidation of quinoline (m/z 129) to the $\mathrm{N}$-oxide form. Fig. 2 shows that quinoline was oxidized, demonstrating the feasibility of using acetic acid and $\mathrm{H}_{2} \mathrm{O}_{2}$ to convert nitrogen compounds present in diesel oil to more polar molecules. No other oxidation product was observed and the mass spectrum was showed up to $\mathrm{m} / \mathrm{z} 150$ in order to fa- cilitate viewing.

\subsection{Effect of $\mathrm{H}_{2} \mathrm{O}_{2}$ volume on nitrogen removal}

Quinoline was selected for the evaluation of UAODN proposed pro- cess because this compound that naturally occurs in crude oils is nor- mally present also in related fuels $[4,22,43]$. A hydrogenated petroleum product feedstock containing $252 \mathrm{mg} \mathrm{kg}^{-1}$ of total nitrogen (as quinoline) was treated by ultrasoundassisted reaction with acetic

acid and hydrogen peroxide, similarly to a previous work [32].

In this study, $25 \mathrm{~mL}$ of petroleum product feedstock and $2.5 \mathrm{~mL}$ of acetic acid were mixed with a variable volume of $50 \% \mathrm{H}_{2} \mathrm{O}_{2}$ (ranging from 0 to $1 \mathrm{~mL}$ ). Ultrasound amplitude was set at $40 \%$ and US was applied during 9 min keeping the reaction mixture at controlled tempera- ture (90 ${ }^{\circ} \mathrm{C}$ ). At the end of this step, the petroleum product feedstock and $\mathrm{AcOH} / \mathrm{H}_{2} \mathrm{O}_{2}$ phases were spontaneously separated. The oil phase was extracted three times ( $3 \mathrm{~mL}$ each) using $\mathrm{MeOH}$ by manual shaking [40]. After US treatment and extraction step, nitrogen concentration was determined in oil phase and the results are shown in Fig. 3.

When hydrogen peroxide was not used, $92 \%$ of nitrogen removal was achieved (Fig. 3). This result can be explained by the extraction of nitrogen compounds by acetic acid during sonication and/or by metha-

nol in liquid-liquid extraction step since no oxidizing agent was used for the reaction. When $0.1 \mathrm{~mL}$ of $\mathrm{H}_{2} \mathrm{O}_{2}$ was used, a small increase in nitrogen removal efficiency (95\%) was observed. For $\mathrm{H}_{2} \mathrm{O}_{2}$ volumes higher than $0.25 \mathrm{~mL}$, no significant improvement was observed (ANOVA, $\mathrm{p} \mathrm{b}$ 0.05 ) and nitrogen removal did not exceed $97 \%$. In spite of quinoline being extracted by acetic acid and methanol not requiring the use of $\mathrm{H}_{2} \mathrm{O}_{2}$, it is still necessary to achieve better ODS efficiency, as shown in previous works $[32,34,44]$. In addition, it can contribute to oxidize other nitrogen compounds which are not soluble in solvent phase and have to be converted to $\mathrm{N}$-oxidized compounds before the extrac-

tion from oil. In this way, the amount of $\mathrm{H}_{2} \mathrm{O}_{2}$ was kept at $0.25 \mathrm{~mL}$ for further experiments.

\subsection{Effect of acetic acid volume on nitrogen removal}

Oxidation experiments were carried out in a combined system using $25 \mathrm{~mL}$ of hydrotreated petroleum product feedstock containing $252 \mathrm{mg} \mathrm{kg}^{-1}$ of nitrogen, $0.25 \mathrm{~mL}$ of $50 \% \mathrm{H}_{2} \mathrm{O}_{2}$ and volume of acetic acid ranging from 0 to $2.5 \mathrm{~mL}$. The oxidative reaction system was kept at $90{ }^{\circ} \mathrm{C}$ and 9 min of US irradiation was applied (set at $40 \%$ of 


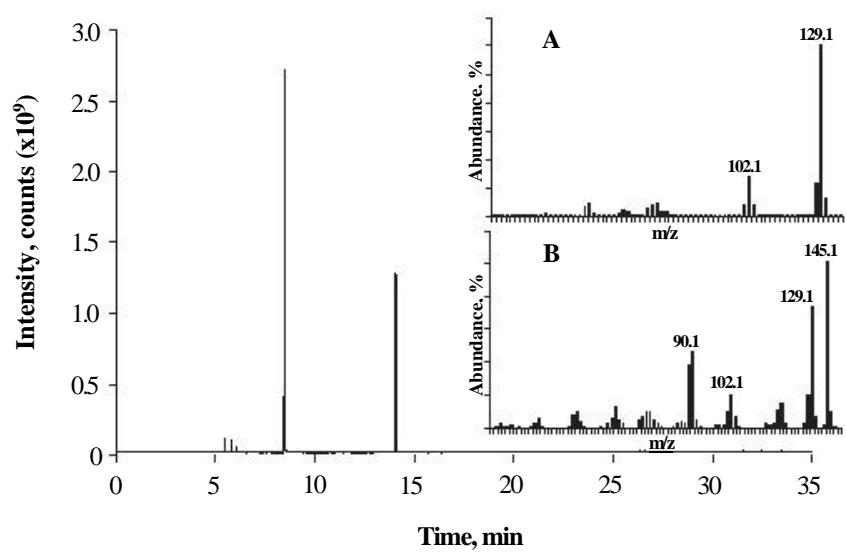

Fig. 2. Chromatogram of quinoline solution after oxidation and the mass spectrum of the peak in 8.49 $\min$ (quinoline, $\mathrm{A}$ ) and in $14.04 \mathrm{~min}(\mathrm{~N}$-oxide, $\mathrm{B})$.

amplitude). At the end of reaction, oil and aqueous phases were separat- ed and the oil phase was extracted three times ( $3 \mathrm{~mL}$ each) using $\mathrm{MeOH}$. To evaluate the effect of acetic acid in the oxidizing mixture, an experi- ment without acetic acid was also performed. The effect of acetic acid on

denitrogenation efficiency is shown in Fig. 4.

Nitrogen removal higher than $95 \%$ was obtained using $2 \mathrm{~mL}$ of glacial acetic acid. The use of higher volumes resulted in slightly better nitro- gen removal. However, it is important to point out that the use of $2.5 \mathrm{~mL}$ of acetic acid did not result in significant improvement in UAODN efficiency. No statistical difference was observed in the experiments using 2 or $2.5 \mathrm{~mL}$ acetic acid and, therefore, acetic acid volumes higher than $2 \mathrm{~mL}$ were considered unnecessary.

It is important to emphasize that the effect of the carboxylic acid on nitrogen removal is more pronounced than $\mathrm{H}_{2} \mathrm{O}_{2}$, as can be observed in experiments without $\mathrm{H}_{2} \mathrm{O}_{2}$ (Fig. 3) and without acetic acid (Fig. 4). For the reactions where only acetic acid and $25 \mathrm{~mL}$ of diesel oil were used, nitrogen removal higher than $92 \%$ was achieved, while less than $88 \%$ was removed when using only $\mathrm{H}_{2} \mathrm{O}_{2}$. Higher efficiency using only acetic acid can be associated to its extractive effect over nitrogen compounds, which may be more pronounced than those presented by $\mathrm{H}_{2} \mathrm{O}_{2}$. In addition, it is important to point out that a pronounced extractive effect was also observed for methanol, which was able to extract about $79 \%$ of nitrogen by applying a liquid-liquid extraction step directly to the oil (without UAODN treatment). This extractive effect of nitrogen compounds can be an important contribution to oxidative desulfurization once nitrogen can be removed by extraction and thus, oxidative reagents would be available to react with sulfur compounds.

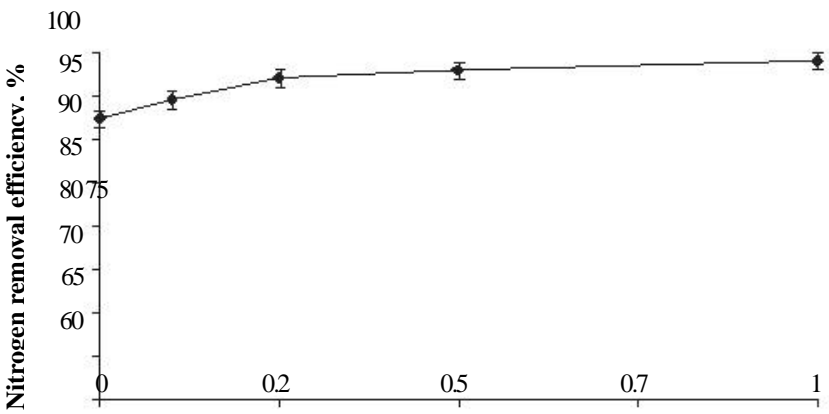

Fig. 3. Effect of the volume of $50 \% \mathrm{H}_{2} \mathrm{O}_{2}$ on nitrogen removal from petroleum product feedstock ( $25 \mathrm{~mL}$ of oil containing $252 \mathrm{mg} \mathrm{kg}^{\perp}$ ofNasquimolineand 25 mLofacticacid, $9 \mathrm{~min}$ of US $20 \mathrm{kHz}$, set at $40 \%$, extraction with $\mathrm{MeOH}$; error bars represent the standard deviation, $\mathrm{n}=3$ ).

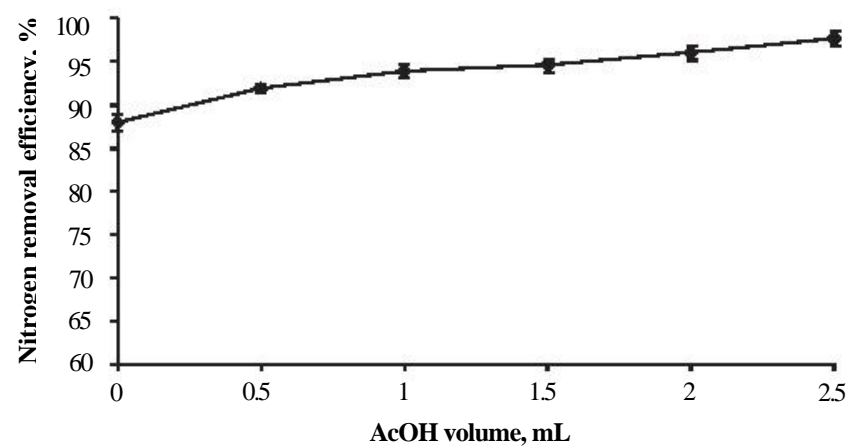

Fig. 4. Influence of acetic acid volume on $\mathrm{N}$ removal from petroleum product feedstock ( $25 \mathrm{~mL}$ of oil containing $252 \mathrm{mg} \mathrm{kg}^{\perp}$ of nitrogenasquinoline and $0.25 \mathrm{~mL}$ of $50 \%$ $\mathrm{H}_{2} \mathrm{O}_{2}$, US $20 \mathrm{kHz}$, set at $40 \%$, extraction with $\mathrm{MeOH}$; error bars represent the standard deviation, $\mathrm{n}=3$ ).

\subsection{Study of ultrasonic irradiation time and amplitude}

Regarding the reduction of the UAODN process time, several exper- iments containing $25 \mathrm{~mL}$ oil, $2 \mathrm{~mL}$ acetic acid and $0.25 \mathrm{~mL}$ of $50 \% \mathrm{H}_{2} \mathrm{O}_{2}$ were performed with reaction times ranging from 1 to $9 \mathrm{~min}$ in a system heated at $90{ }^{\circ} \mathrm{C}$. The extraction step after oxidation reaction was per- formed with $\mathrm{MeOH}$ and the obtained results are shown in Fig. 5.

It is possible to observe that nitrogen removal efficiency up to $93 \%$ was obtained under only $1 \mathrm{~min}$ of sonication. However, after $5 \mathrm{~min}$ of US, nitrogen removal was $97 \%$ and no significant improvement was obtained for longer sonication times. In this sense, the time of 5 min was selected for further experiments.

Ultrasonic amplitudes of 30 to $70 \%$ were evaluated in a series of $5 \mathrm{~min}$ sonication experiments at $90{ }^{\circ} \mathrm{C}$ under optimized conditions ( $2 \mathrm{~mL}$ of acetic acid and $0.25 \mathrm{~mL}$ of $50 \% \mathrm{H}_{2} \mathrm{O}_{2}$ for the treatment of $25 \mathrm{~mL}$ of diesel oil). No statistical difference in nitrogen removal was observed for evaluated amplitudes (ANOVA, p b 0.05) and a denitrogenation efficiency of at least $95 \%$ was obtained. Therefore, amplitude of $40 \%$ was selected for subsequent experiments, as it was previously observed to be more efficient for sulfur removal $[32,40]$.

\subsection{Extraction step}

Some works have reported the hydroxylation of both quinoline rings after the oxitreatment of diesel oil containing quinoline. The presence of these hydroxyl groups increases polarity, enabling the use of alternative nitrogen removal methods such as adsorption and solvent based extrac-

tion. It is important to point out that the solvent in liquid-liquid oil extraction must present high polarity and be insoluble in fuel matrix $[3,25]$. Therefore, methanol, ethanol and water were evaluated as sol- vent in the extraction step. A solvent:diesel oil ratio of 0.36 was chosen based on preliminary results using ultrasound-assisted oxidative

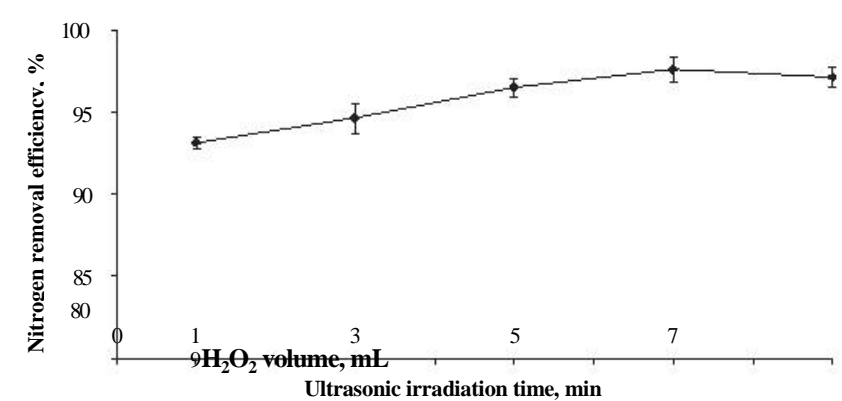

Fig. 5. Influence of US irradiation time on $\mathrm{N}$ removal $(25 \mathrm{~mL}$ of oil containing $252 \mathrm{mg} \mathrm{kg}$ ᄀ of $\mathrm{N}$ as quinoline, $2 \mathrm{~mL}$ of acetic acid, $0.25 \mathrm{~mL}$ of $50 \% \mathrm{H}_{2} \mathrm{O}_{2}$ solution, US $20 \mathrm{kHz}$, set at $40 \%$, extraction with $\mathrm{MeOH}$; error bars represent the standard deviation, $\mathrm{n}=3$ ). 
process with further liquid-liquid extraction [40]. Thus, experiments were performed with $25 \mathrm{~mL}$ of diesel oil enriched with quinoline, following the experimental conditions previously optimized.

Using ethanol, the denitrogenation efficiency was $91.6 \pm 2.5 \%(\mathrm{n}=3)$, but a partial solubility of this solvent in diesel oil after the extraction step (ca. 5\% in mass) was observed, making ethanol useless for this purpose. Nitrogen removal of $95.5 \pm 1.1 \%$ was obtained using methanol and a similar efficiency $(96.4 \pm 1.9 \%)$ was observed when water was used as the extraction solvent. In order to avoid the addition of water to petroleum derivatives after the refining process, and considering that methanol is more efficient than water to extract oxidized sulfur compounds [32], methanol was chosen to perform the extraction after the oxidative denitrogenation process as well as for subsequent experiments. It is im- portant to mention that due to the wide number of nitrogen and sulfur compounds in fuels, the characteristics of oxidized compounds may re- quire a change in solvent. In this way, it would be necessary to evaluate the ideal solvent for each organonitrogen and/or organo-sulfur class when this process is applied to other structures [45].

\subsection{Effect of quinoline on the oxidative desulfurization of dibenzothiophene}

Although the concentration of nitrogen compounds is usually lower than sulfur compounds, it has been reported that the presence of nitro- gen even in relatively low concentration can decrease desulfurization activity in fuels $[15,46]$. According to Caero et al. [13], quinoline was re- ported to have higher inhibitory effect on oxidative desulfurization ac- tivity when compared with indole and carbazole. In order to evaluate the effect of quinoline on UAODS process, a hydrotreated petroleum product feedstock containing $211 \mathrm{mg} \mathrm{kg}^{-1}$ of sulfurwas preparedbyusing dibenzothiophene as model compound. This solution was enriched with different amounts of quinoline as the nitrogen source, resulting in S:N molar ratios of $1: 0.1 ; 1: 0.3 ; 1: 0.5 ; 1: 1$ and $1: 2$. Reactions were performed during $9 \mathrm{~min}$ of US, $2 \mathrm{~mL}$ of acetic acid, $0.25 \mathrm{~mL}$ of $50 \%$

$\mathrm{H}_{2} \mathrm{O}_{2}$ at $90{ }^{\circ} \mathrm{C}$ and $40 \%$ of amplitude. The effect of nitrogen (as quinoline) on sulfur removal is shown in Fig. 6.

Sulfur removal was $96 \%$ when nitrogen was virtually absent in the evaluated feedstock (data not shown in Fig. 6). In this sense, considering the results presented in Fig. 6, it can be concluded that quinoline presents an adverse impact on sulfur removal even at a $\mathrm{S}: \mathrm{N}$ molar ratio of 1:0.1. This ratio corresponds to a nitrogen concentration of $9.2 \mathrm{mg} \mathrm{kg}^{-1}$, and itsimpact is more adverse as nitrogen contentin-creases. Similar nitrogen compound effects on the desulfurization of diesel oil feedstock [15] on a model fuel sample [46] were observed for both hydrodesulfurization and catalytic oxidative processes. Nitro- gen removal was always close to $100 \%$ while sulfur removal gradually decreased at lower S:N molar ratios. For this reason, it was possible to consider that nitrogen compounds are more prone to be removed

from diesel oil than sulfur compounds, considering the same oxidative

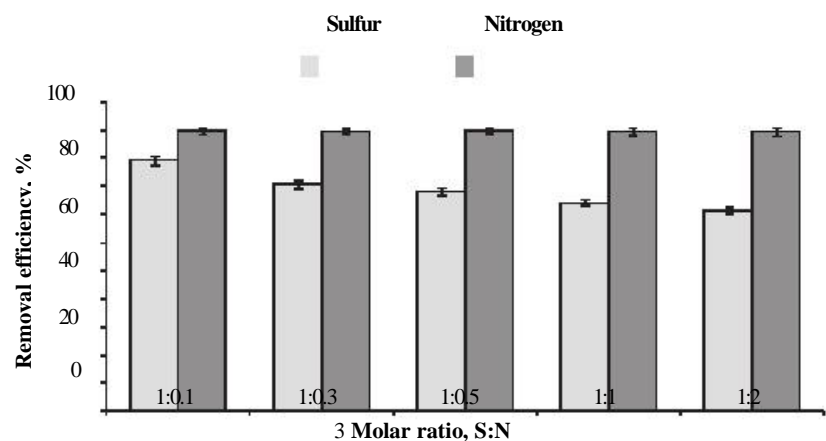

Fig. 6. Effect of quinoline content on the UAOD process for dibenzothiophene removal at different S: $\mathrm{N}$ molar ratios in model oil $\left(25 \mathrm{~mL}\right.$ of oil containing $211 \mathrm{mg} \mathrm{kg}^{-}$ofsulfuras dibenzothiophene, $2 \mathrm{~mL}$ of acetic acid, $0.25 \mathrm{~mL}$ of $50 \% \mathrm{H}_{2} \mathrm{O}_{2}$ solution, US $20 \mathrm{kHz}$, set at $40 \%$, extraction with $\mathrm{MeOH}$; error bars represent the standard deviation, $\mathrm{n}=3$ ). conditions. In addition, the extractive effect of acetic acid and methanol also contributes for higher nitrogen removal efficiency, minimizing the effect of nitrogen over sulfur removal efficiency.

\subsection{Application of UAODN procedure in petroleum derivatives}

Once UAODN parameters were optimized, the application of pro- posed procedure was carried out for nitrogen removal in five diesel oil samples (D1, D2, D3, D4 and D5) using $25 \mathrm{~mL}$ diesel oil, $2.0 \mathrm{~mL}$ acetic acid, $0.25 \mathrm{~mL} 50 \% \mathrm{H}_{2} \mathrm{O}_{2}, 90{ }^{\circ} \mathrm{C}$, ultrasound $20 \mathrm{kHz}$, set at $40 \%$ of amplitude during $5 \mathrm{~min}$, and extraction with $3 \times 3 \mathrm{~mL}$ of $\mathrm{MeOH}$. Nitrogen and sulfur removal efficiencies were also determined for a reaction time of 9 min [40]. At the same time, the effect of nitrogen on sulfur removal was observed for diesel oil samples with $\mathrm{S}: \mathrm{N}$ molar ratios of 1:2.40 (D1), 1:2.07 (D2), 1:1.60 (D3), 1:0.85 (D4), and 1:0.52 (D5). It is important to point out that the experiments without US (mechanical stirring, $2000 \mathrm{rpm}$ ) were performed at the same time (9 min). Results obtained for nitrogen and sulfur removal in diesel oil samples are shown in Fig. 7.

According to the results presented in Fig. 7, higher nitrogen and sulfur removal was observed using 9 min of reaction when compared to 5 min of US treatment. In addition, denitrogenation efficiency was considerably affected when US was substituted by mechanical stirring. Nitrogen content remaining in diesel oil after oxidative treatment with mechanical stirring was about twice when compared to US treat- ment by 9 min (correspondent to an additional improvement in $\mathrm{N}$ removal from 15 to $22 \%$ using US by $9 \mathrm{~min}$ ). In a similar way, the desul-

furization efficiency using US was higher for $9 \mathrm{~min}$ when compared to 5 min, and the use of mechanical stirring resulted in significant efficiency decrease (from 20 to $40 \%$ less efficient using mechanical stirring when compared to 9 min using US). In general, the effect of US on oxidative desulfurization is more remarkable than that observed for oxidative denitrogenation.
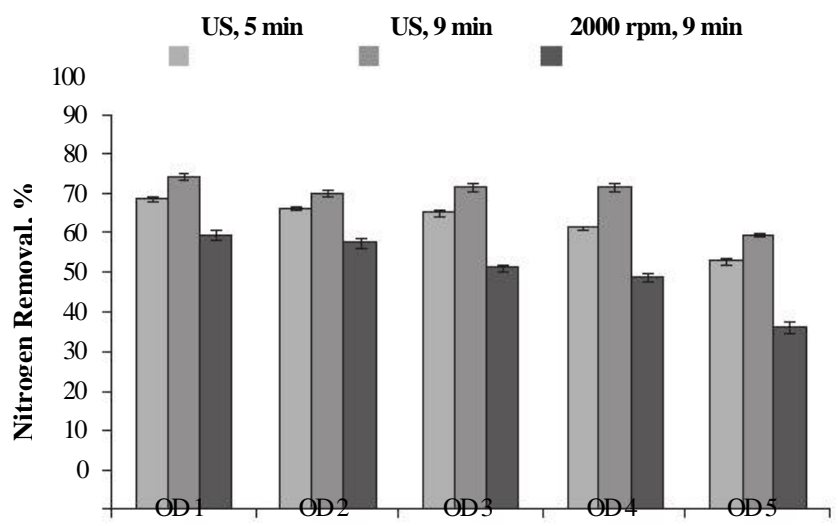

100

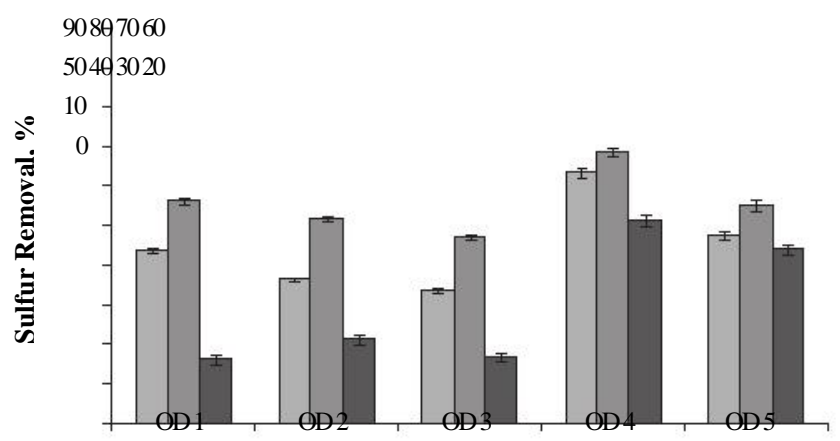

Fig. 7. Effect of US and mechanical stirring on nitrogen and sulfur removal from diesel oil samples ( $25 \mathrm{~mL}$ of oil, $2 \mathrm{~mL}$ of acetic acid, $0.25 \mathrm{~mL}$ of $50 \% \mathrm{H}_{2} \mathrm{O}_{2}$ solution, US $20 \mathrm{kHz}$, set at $40 \%$; or $2000 \mathrm{rpm}$, extraction with $\mathrm{MeOH}$; error bars represent the standard deviation, $\mathrm{n}=3$ ). 
Table 4

Diesel oil characterization after UAODN process. Values in brackets correspond to the variation of density or viscosity in relation to the original values.

\begin{tabular}{lll}
\hline Diesel oil & Density $\left(\mathrm{g} \mathrm{cm}^{-3}, 20^{\circ} \mathrm{C}\right)$ & Viscosity $\left(\mathrm{mm}^{2} \mathrm{~s}^{\perp}, 40^{\circ} \mathrm{C}\right)$ \\
\hline D1 & $0.8634(+0.5 \%)$ & $3.8997(+0.4 \%)$ \\
D2 & $0.8623(+0.6 \%)$ & $4.2140(-0.8 \%)$ \\
D3 & $0.8628(+0.6 \%)$ & $4.2802(+0.8 \%)$ \\
D4 & $0.8492(+0.2 \%)$ & $2.7150(-0.3 \%)$ \\
D5 & $0.8451(+0.4 \%)$ & $2.4279(-1.0 \%)$ \\
\hline
\end{tabular}

Considering the results obtained for all diesel oil samples, the infor-

mation about the S:N molar ratio can be suitable to estimate the efficiency of an oxidative treatment under US. However, nitrogen and sulfur contents in diesel oil are associated to a wide variety of com- pounds, which are related to have variable reactivity and solubility in organic solvents used for liquid-liquid extraction, besides the presence of alkyl substituent, mainly derived from sulfur compounds [24]. Thus, in order to identify these sulfur compounds in diesel oil, samples were analyzed by gas chromatography with pulsed flame photometric detector (GC-PFPD). Table S1 and Figs. S1 to S6 (please, see in Supporting Information Section) illustrate chromatographic conditions and the GC- PFPD chromatograms for standard solution (Fig. S1) and original diesel oil samples (Figs. S2 to S6). In addition, chromatograms in Figs. S7 to S11 show the profile of sulfur compounds remaining in samples after the ultrasound-assisted oxidative treatment.

Although the nitrogen content remaining in treated diesel oil sam- ples was higher than $9.2 \mathrm{mg} \mathrm{kg}^{-1}$, which was observed tohave anega-tive effect on sulfur removal process, the proposed UAODN procedure can be applied successfully as a complement to the HDS process. It could be also considered as an alternative way to reduce the nitrogen content in diesel oil, allowing sulfur removal to be carried out at higher

efficiency and using relatively milder conditions.

Some works have reported that no effect is observed on the general properties of fuel samples treated by oxidative desulfurization process, such as distillation curves, density and others $[44,47]$. Therefore, in order to evaluate possible changes in diesel oil characteristics, density and dynamic viscosity were determined before and after the proposed UAODN procedure (Table 4). It is possible to observe in Table 4 that die- sel oil density and viscosity were very similar to original values (see Table 3 ) after the UAODN process, which indicates that these character- istics were not affected by ultrasound-assisted oxidative treatment. In addition, diesel oil recovery after oxidation under US and extraction with methanol was $96 \%$, but it is important to point out that an oil recovery significantly better should be obtained with the scale up of the proposed process.

The characteristics of the UAODN process are summarized in Table 5 and compared to other process proposed for nitrogen removal from liquid fuel via oxidative denitrogenation. It is important to mention that if the procedure using $\mathrm{H}_{2} \mathrm{O}_{2}$ and acetic acid is carried out in the absence of US, lower sulfur removal is obtained, as previously described [40]. According to these data, the use of US to promote simultaneous denitrogenation and desulfurization efficiency in a shorter time is evidenced, demonstrating the use of this technology as a promising tool for process improvement.

\section{Conclusions}

It was found that the combination of acetic acid and $\mathrm{H}_{2} \mathrm{O}_{2}$ can pro- mote an efficient ultrasound-assisted oxidative desulfurization, even for diesel oils with relatively high concentration of nitrogen. Effectiveness of nitrogen removal was higher than those presented for sulfur removal efficiency using the same oxidative conditions. It can be associated to the higher solubility of nitrogen compounds in acetic acid and methanol, either in original or oxidized forms. As previously re-ported, the ultrasound-assisted oxidative procedure is a promising way of removing sulfur and nitrogen from petroleum derivatives, but the reactivity of nitrogen and sulfur molecules was not the same under specific oxidative conditions. The inhibiting effect of quinoline on dibenzothiophene oxidation under acetic acid/ $\mathrm{H}_{2} \mathrm{O}_{2}$ and US irradiation was observed at nitrogen concentrations of as low as $9.2 \mathrm{mg} \mathrm{kg}^{-1}$,corresponding to a $\mathrm{S}: \mathrm{N}$ molar ratio of 1:0.1. In spite of Brazilian fuel regula- tions to establish only sulfur maximum content present in diesel oil, it is important to consider that the proposed procedure allowed an efficient and simultaneous sulfur and nitrogen removal, which was performed free of interference as well as the application of extreme conditions. Ad- ditionally, the comparison between US and mechanical stirring showed the remarkable effect of ultrasonic energy in reaction medium, promot- ing better interaction of immiscible liquids and higher oxidation rates of nitrogen and sulfur compounds. In this way, ultrasound-assisted oxida- tive process for sulfur and nitrogen removal may be proposed as a com- plementary step to hydrogenation, as well as pretreatment for

hydrocracking and fluid catalytic cracking, since the major part of nitrogen is removed in the same step. Finally, the application of optimized conditions to diesel oil samples allowed high sulfur and nitrogen re- moval (up to 69 and $84 \%$ for 9 min of reaction, respectively) to be attained while not affecting other diesel properties as density, viscosity and distillation temperature.

\section{Acknowledgments}

The authors are grateful to CENPES/PETROBRAS S. A. for donation of samples and financial support and also to CNPq, CAPES and FAPERGS for supporting this study.

Table 5

Oxidative processes proposed for denitrogenation of fuel oils.

\begin{tabular}{|c|c|c|c|}
\hline Oxidizing mixture & Sample and nitrogen content & Characteristics & Reference \\
\hline Acetic acid and hydrogen peroxide & Model quinoline solution and 5 hydrotreated diesel oils with & $25 \mathrm{~mL}$ of oil, $2.0 \mathrm{~mL}$ acetic acid and $0.25 \mathrm{~mL} \mathrm{H}_{2} \mathrm{O}_{2}$. Reaction & This work \\
\hline & nitrogen content between 86 and $226 \mathrm{mg} \mathrm{kg}\urcorner$ & time of 9 min at $90^{\circ} \mathrm{C}$ with US $(20 \mathrm{kHz})$. Extraction with & \\
\hline $\begin{array}{l}\text { Limonite ore, hydrogen peroxide } \\
\text { and formic acid }\end{array}$ & Quinoline in water $\left(10 \mathrm{mg} \mathrm{L}^{\lrcorner}\right)$ & $\begin{array}{l}3 \times 3 \mathrm{~mL} \text { of methanol. Nitrogen removal was from } 69 \text { to } 84 \% \text {. } \\
10 \mathrm{~mL} \text { of quinoline solution, } 10 \mathrm{mg} \text { of limonite ore and } \\
\text { equimolar amounts ( } 97 \mathrm{mmol} \text { ) of } \mathrm{H}_{2} \mathrm{O}_{2} \text { and formic acid. } \\
\text { Reaction time of } 360 \text { min under magnetic stirring at } 25{ }^{\circ} \mathrm{C} \text {. } \\
\text { Quinoline removal was } 90 \% \text {. }\end{array}$ & [3] \\
\hline $\begin{array}{l}\text { Tert-butyl hydroperoxide and } \\
\qquad \mathrm{MoO}_{3} / \mathrm{Al}_{2} \mathrm{O}_{3} \text { as catalyst }\end{array}$ & $\begin{array}{l}\text { Indole, quinoline, acridine and carbazole ( } 20 \mathrm{mg} \mathrm{kg}^{\perp} \text { ofN } \\
\left.\text { in decalin); light gas oil ( } 13.5 \mathrm{mg} \mathrm{kg}^{\perp} \text { ofN }\right)\end{array}$ & $\begin{array}{l}\text { Flow reaction in a stainless steel tube with } 1 \mathrm{~mL} \text { of catalyst and a } \\
\text { reactor with } 20 \mathrm{~mL} \text { of silica gel. Reaction time } 3 \mathrm{~h} \text { at } 80{ }^{\circ} \mathrm{C} \text {. The O:S } \\
\text { molar ratio was } 15: 1 \text { and nitrogen removal was about } 94 \% \text {. }\end{array}$ & [25] \\
\hline Acetic acid and hydrogen peroxide & $\begin{array}{l}\text { Aniline, indole and carbazole ( } 20 \mathrm{mmol} \mathrm{L}^{-} \text {inxylene); } \\
\text { commercial light oil (CLO, } 80.4 \mathrm{mg} \mathrm{kg}^{-} \text {ofN), straight-unlight gas oil } \\
\left(\mathrm{LGO}, 160 \mathrm{mg} \mathrm{kg}^{-1} \text { ofN)and light cycleoil( }(\mathrm{CO} \text {, }\right. \\
243.1 \mathrm{mg} \mathrm{kg}^{-} \text {ofN) }\end{array}$ & $\begin{array}{l}50 \mathrm{~mL} \text { of oil, } \mathrm{H}_{2} \mathrm{O}_{2} \text { and acetic acid using a } \mathrm{S}: \mathrm{H}_{2} \mathrm{O}_{2}: \text { Acetic acid } \\
\text { molar ratio of } 1: 1000: 500 \text {. Reaction time of } 30 \mathrm{~h} \text { at } 70{ }^{\circ} \mathrm{C} \text {. } \\
\text { Extraction with } 50 \mathrm{~mL} \text { of water and } 50 \mathrm{~mL} \text { of acetonitrile/ water } \\
(84 / 16 \mathrm{v} / \mathrm{v}) . \text { Nitrogen removal of } 58.2 \% \text { (CLO), } 43.7 \% \text { (LGO) and } \\
62.1 \% \text { (LCO) was obtained. }\end{array}$ & [26] \\
\hline
\end{tabular}




\section{Appendix A. Supplementary data}

Supplementary data to this article can be found online at http://dx. doi.org/10.1016/j.fuproc.2014.05.031.

\section{References}

[1] United States Environmental Protection Agency, (http://www.epa.gov) Regulatory Announcement: Heavy-Duty Engine and Vehicle Standards and Highway Diesel Fuel Sulfur Control Requirements, December, 2000

[2] C.S. Song, An overview of new approaches to deep desulfurization for ultra-clean gasoline, diesel fuel and jet fuel, Catalysis Today 86 (2003) 211-263.

[3] W.F. de Souza, I.R. Guimaraes, M.C. Guerreiro, L.C.A. Oliveira, Catalytic oxidation of sulfur and nitrogen compounds from diesel fuel, Applied Catalysis A: General 360 (2009) 205-209.

[4] E. Furimsky, Hydrodenitrogenation of petroleum, Catalysis Reviews - Science and Engineering 47 (2005) 297-489.

[5] M. Shavandi, M. Sadeghizadeh, A. Zomorodipour, K. Khajeh, Biodesulfurization of dibenzothiophene by recombinant Gordonia alkanivorans RIPI90A, Bioresource Technology 100 (2009) 475-479.

[6] A. Aminsefat, B. Rasekh, M.R. Ardakani, Biodesulfurization of dibenzothiophene by Gordonia sp AHV-01 and optimization by using of response surface design procedure, Microbiology 81 (2012) 154-159.

[7] H. Gao, Y. Li, Y. Wu, M. Luo, Q. Li, J. Xing, H. Liu, Extractive desulfurization of fuel using 3-methylpyridinium-based ionic liquids, Energy \& Fuels 23 (2009) 2690-2694.

[8] C. Zhang, X. Pan, F. Wang, X. Liu, Extraction-oxidation desulfurization by pyridinium-based task-specific ionic liquids, Fuel 102 (2012) 580-584.

[9] E.C. Gaudino, D. Carnaroglio, L. Boffa, G. Cravotto, E.M. Moreira, M.A.G. Nunes, V.L. Dressler, E.M.M. Flores, Efficient $\mathrm{H} 2 \mathrm{O} 2 / \mathrm{CH} 3 \mathrm{COOH}$ oxidative desulfurization/denitrification of liquid fuels in sonochemical flow-reactors, Ultrasonics Sonochemistry 21 (2014) 283288 .

[10] W. Guo, C. Wang, P. Lin, X. Lu, Oxidative desulfurization of diesel with TBHP/isobutyl aldehyde/air oxidation system, Applied Energy 88 (2011) 175-179.

[11] A. Di Giuseppe, M. Crucianelli, F. De Angelis, C. Crestini, R. Saladino, Efficient oxidation of thiophene derivatives with homogeneous and heterogeneous MTO/ $\mathrm{H}_{2} \mathrm{O}_{2}$ systems: a novel approach for, oxidative desulfurization (ODS) of diesel fuel, Applied Catalysis B: Environmental 89 (2009) 239-245.

[12] Y. Nie, Y. Dong, L. Bai, H. Dong, X. Zhang, Fast oxidative desulfurization of fuel oil using dialkylpyridinium tetrachloroferrates ionic liquids, Fuel 103 (2013) 997-1002.

[13] L. Cedeno Caero, J.F. Navarro, A. Gutierrez-Alejandre, Oxidative desulfurization of synthetic diesel using supported catalysts: part II. Effect of oxidant and nitrogencompounds on extraction-oxidation process, Catalysis Today 116 (2006) 562-568.

[14] M. Sau, K. Basak, U. Manna, M. Santra, R.P. Verma, Effects of organic nitrogen compounds on hydrotreating and hydrocracking reactions, Catalysis Today 109 (2005) 112-119.

[15] G.C. Laredo, J.A. De los Reyes, J.L. Cano, J.J. Castillo, Inhibition effects of nitrogen compounds on the hydrodesulfurization of dibenzothiophene, Applied Catalysis A General 207 (2001) 103-112.

[16] Y. Bai, Q. Sun, C. Zhao, D. Wen, X. Tang, Simultaneous biodegradation of pyridine and quinoline by two mixed bacterial strains, Applied Microbiology and Biotechnology 82 (2009) 963-973.

[17] J.J. Kilbane, R. Ranganathan, L. Cleveland, K.J. Kayser, C. Ribiero, M.M. Linhares, Selective removal of nitrogen from quinoline and petroleum by Pseudomonas ayucida IGTN9m, Applied and Environmental Microbiology 66 (2000) 688-693.

[18] G. Castorena, M. Elena Acuna, J. Aburto, I. Bustos-Jaimes, Semi-continuous biodegradation of carbazole in fuels by biofilm-immobilised cells of Burkholderia sp. strain IMP5GC, Process Biochemistry 43 (2008) 1318-1321.

[19] M. Matsumoto, M. Mikami, K. Kondo, Separation of organic nitrogen compounds by supported liquid membranes based on ionic liquids, Journal of the Japan Petroleum Institute 49 (2006) 256-261

[20] M. Almarri, X. Ma, C. Song, Selective adsorption for removal of nitrogen compounds from liquid hydrocarbon streams over carbon- and alumina-based adsorbents, Industrial \& Engineering Chemistry Research 48 (2009) 951-960.

[21] D. Liu, J. Gui, Z. Sun, Adsorption structures of heterocyclic nitrogen compounds over $\mathrm{Cu}(\mathrm{I}) \mathrm{Y}$ zeolite: a first principle study on mechanism of the denitrogenation and the effect of nitrogen compounds on adsorptive desulfurization, Journal of Molecular Catalysis A: Chemical 291 (2008) 17-21

[22] L. da Conceicao, C.L. de Almeida, S. Egues, R.M. Dallago, N. Paroul, I. do Nascimento, W.F. de Souza, S.B.C. Pergher, Preliminary study of the oxidation of nitrogen compounds of gas oil from Brazilian petroleum, Energy \& Fuels 19 (2005) 960-963.
[23] A. Ishihara, D.H. Wang, F. Dumeignil, H. Amano, E.W.H. Qian, T. Kabe, Oxidative desulfurization and denitrogenation of a light gas oil using an oxidation/adsorption continuous flow process, Applied Catalysis A: General 279 (2005) 279-287.

[24] Y. Shiraishi, K. Tachibana, T. Hirai, I. Komasawa, Desulfurization and denitrogenation process for light oils based on chemical oxidation followed by liquid-liquid extraction, Industrial \& Engineering Chemistry Research 41 (2002) 4362-4375.

[25] L.F. Ramirez-Verduzco, E. Torres-Garcia, R. Gomez-Quintana, V. Gonzalez-Pena, F. Murrieta-Guevara, Desulfurization of diesel by oxidation/extraction scheme: influence of the extraction solvent, Catalysis Today 98 (2004) 289-294.

[26] F. Zannikos, E. Lois, S. Stournas, Desulfurization of petroleum fractions by oxidation and solvent-extraction, Fuel Processing Technology 42 (1995) 35-45.

[27] P. De Filippis, M. Scarsella, Oxidative desulfurization: oxidation reactivity of sulfur compounds in different organic matrixes, Energy \& Fuels 17 (2003) 1452-1455.

[28] G. Cravotto, E.C. Gaudino, P. Cintas, On the mechanochemical activation by ultrasound, Chemical Society Reviews 42 (2013) 7521-7534.

[29] D. Pingret, A.-S. Fabiano-Tixier, F. Chemat, Degradation during application of ultrasound in food processing: a review, Food Control 31 (2013) 593-606.

[30] B.G. Pollet, J.P. Lorimer, J.Y. Hihn, S.S. Phull, T.J. Mason, D.J. Walton, The effect of ultrasound upon the oxidation of thiosulphate on stainless steel and platinum electrodes, Ultrasonics Sonochemistry 9 (2002) 267-274.

[31] K.S. Suslick, D.J. Flannigan, Inside a collapsing bubble: sonoluminescence and the conditions during cavitation, Annual Review of Physical Chemistry, 2008, pp. 659-683.

[32] P.A. Mello, F.A. Duarte, M.A.G. Nunes, M.S. Alencar, E.M. Moreira, M. Korn, V.L. Dressler, E.M.M. Flores, Ultrasound-assisted oxidative process for sulfur removal from petroleum product feedstock, Ultrasonics Sonochemistry 16 (2009) 732-736.

[33] M.-W. Wan, T.-F. Yen, Enhance efficiency of tetraoctylarnmoniurn fluoride applied to ultrasound-assisted oxidative desulfurization (UAOD) process, Applied Catalysis A: General 319 (2007) 237-245.

[34] H. Mei, B.W. Mei, T.F. Yen, A new method for obtaining ultra-low sulfur diesel fuel via ultrasound assisted oxidative desulfurization, Fuel 82 (2003) 405-414.

[35] A. Deshpande, A. Bassi, A. Prakash, Ultrasound-assisted, base-catalyzed oxidation of 4,6-dimethyldibenzothiophene in a biphasic diesel-acetonitrile system, Energy \& Fuels 19 (2005) 28-34.

[36] Y. Dai, Y. Qi, D. Zhao, H. Zhang, An oxidative desulfurization method using ultrasound/Fenton's reagent for obtaining low and/or ultra-low sulfur diesel fuel, Fuel Processing Technology 89 (2008) 927-932

[37] ASTM International, Annual Book of ASTM Standards, ASTM D 4629-96, Standard Test Method for Trace Nitrogen in Liquid Petroleum Hydrocarbons by Syringe/Inlet Oxidative Combustion and Chemiluminescence Detection, in, West Conshohocken, USA, 1996

[38] ASTM International, Annual Book of ASTM Standards, ASTM D 5453-06, Standard Test Method for Determination of Total Sulfur in Light Hydrocarbons, Spark Ignition Engine Fuel, Diesel Engine Fuel, and Engine Oil by Ultraviolet Fluorescence, in, West Conshohocken, USA, 2006

[39] ASTM International, Annual Book of ASTM Standards, ASTM D 7042-04, Standard Test Method for Dynamic Viscosity and Density of Liquids by Stabinger Viscometer and the Calculation of Kinematic Viscosity, in, West Conshohocken, USA, 2004.

[40] F.A. Duarte, P.d.A. Mello, C.A. Bizzi, M.A.G. Nunes, E.M. Moreira, M.S. Alencar, H.N. Motta, V.L. Dressler, E.M.M. Flores, Sulfur removal from hydrotreated petroleum- fractions using ultrasound-assisted oxidative desulfurization process, Fuel 90 (2011) 2158-2164.

[41] T. Kimura, T. Sakamoto, J.M. Leveque, H. Sohmiya, M. Fujita, S. Ikeda, T. Ando, Standardization of ultrasonic power for sonochemical reaction, Ultrasonics Sonochemistry 3 (1996) S157-S161.

[42] T.J. Mason, A.J. Cobley, J.E. Graves, D. Morgan, New evidence for the inverse dependence of mechanical and chemical effects on the frequency of ultrasound, Ultrasonics Sonochemistry 18 (2011) 226-230.

[43] D. Singh, A. Chopra, M.B. Patel, A.S. Sarpal, A comparative evaluation of nitrogen compounds in petroleum distillates, Chromatographia 74 (2011) 121-126.

[44] A.M. Dehkordi, M.A. Sobati, M.A. Nazem, Oxidative desulfurization of nonhydrotreated kerosene using hydrogen peroxide and acetic acid, Chinese Journal of Chemical Engineering 17 (2009) 869-874.

[45] L.F. Ramirez-Verduzco, J.A.D.I. Reyes, E. Torres-Garcia, Solvent effect in homogeneous and heterogeneous reactions to remove dibenzothiophene by an oxidationextraction scheme, Industrial \& Engineering Chemistry Research 47 (2008) 5353-5361.

[46] Y. Jia, G. Li, G. Ning, C. Jin, The effect of N-containing compounds on oxidative desulphurization of liquid fuel, Catalysis Today 140 (2009) 192-196.

[47] Y. Dai, Y. Qi, D. Zhao, Effect of various sono-oxidation parameters on the desulfurization of diesel oil, Petroleum Chemistry 49 (2009) 436-441. 